\title{
In vitro degradative effect of purified zearalenone with or without adsorbents after bionic digestion
}

\author{
Jian-Wei GAO ${ }^{1 * \#}\left(\mathbb{D}\right.$, Hong-Fu ZHANG ${ }^{2 *}$, Shi-Chun PEI ${ }^{3 \#}$, Hao-Nan ZHANG ${ }^{1}$
}

\begin{abstract}
The occurrence of zearalenone is considered a major risk factor affecting human and animal health worldwide. Zearalenonecontaminated feed can cause serious disorders and diseases in farm animals. A number of approaches have been developed to counteract zearalenone, but only few can be used. A potential approach to protecting animals against the harmful effects of zearalenone-contaminated feed is the use of substances to reduce zearalenone contamination of feed. The present study aimed to evaluate the effect of different absorbents in zearalenone-contaminated feed via in vitro bionic digestion. The results revealed that three types of absorbents exhibit improved effects. More than $50 \%$ of zearalenone is absorbed during digestion. Specifically, KLX (the main component is yeast cell wall), absorbed $83 \%$ of the zearalenone in the contaminated feed after bionic digestion in vitro. Monogastric animal bionic digestion is a rapid and physiologically relevant method to evaluate the efficacy of adsorbent materials in binding mycotoxins. The technique can be used to pre-screen the mycotoxin/adsorbent combinations as an alternative to animal experiments.
\end{abstract}

Keywords: zearalenone; bionic digestion system; adsorbent.

Practical Application: Approach to protecting animals against the harmful effects of zearalenone-contaminated feed.

\section{Introduction}

Zearalenone (ZEN) is a nonsteroidal estrogenic mycotoxin mainly produced by Fusarium graminearium and Fusarium culmorum found in various host plant-soil debris worldwide, causing hyperestrogenism and related toxicoses in farm animals and humans. ZEN is present as a contaminant in cereals such as maize, barley, wheat, rice, oats, rye, and sorghum (Pittet, 1998; Tanaka et al., 1988), as well as in processed cereal-based food such as flakes and bread (Betina, 1989; Aziz et al., 1997), corn pancakes (Groves et al., 1999), and beer (Martin \& Keen, 1978; Okoye, 1987).

ZEN is a resorcyclic acid lactone chemically described as 6-[10-hydroxy-6-oxo- trans-1-undecenyl]-B-resorcyclic acid lactone. ZEN was assigned the trivial name zearalenone as a combination of Gibberella zeae, resorcylic acid lactone, -ene (for the presence of the C-1' to C-2' double bond) and -one for the C-6'ketone content (Urry et al., 1966).

The Food and Agriculture Organization (FAO) estimates that at least $25 \%$ of cereal production worldwide is contaminated with mycotoxins (Dowling, 1997). ZEN is the major Fusarium mycotoxin that occurs in cereal grains, animal feeds, and forages worldwide. Spontaneous outbreaks of Fusarium mycotoxins have been reported in Europe, Asia, New Zealand, and South America (D’Mello et al., 1999).
The Joint FAO/WHO Expert Committee on Food Additive (JECFA) has established a provisional maximum tolerable daily intake (PMTDI) for ZEN and its metabolites of $0.5 \mu \mathrm{g} / \mathrm{kg}$ of body weight per day (Joint FAO/WHO Expert Committee on Food Additives, 2000). ZEN intoxication exhibits the highest risk for farm animals owing to the frequency of its occurrence in cereals. Therefore, six countries (Austria, Brazil, France, Romania, Russia, and Uruguay) have set guidelines or maximum tolerable levels of ZEN at $30-1000 \mu \mathrm{g} / \mathrm{kg}$ in some foods. ZEN has been reported in wheat at $11-860 \mu \mathrm{g} / \mathrm{kg}$ (Schneweis, I. et al, 2002). Cyprus, Hungary, and the Netherlands have set a maximum tolerated concentration for all mycotoxins at $0-0.05 \mu \mathrm{g} / \mathrm{kg}$ in some foods. In China, the maximum limits for ZEN are $60 \mu \mathrm{g} / \mathrm{kg}$ in wheat and corn and $500 \mu \mathrm{g} / \mathrm{kg}$ in animal feed (Zhang et al., 2011).

Chicken seems to exhibit high tolerance to ZEN. A study found that diets containing up to $800 \mathrm{mg} / \mathrm{kg}$ feed for $7 \mathrm{~d}$ induced no signs of toxicity nor impaired the reproductive performance of mature chickens (Chi et al., 1980). High levels of ZEN may cause the swelling of the vent and an increase in the size of the oviduct (Allen et al., 1981). A hyper androgenic response was observed in male turkeys fed with $800 \mu \mathrm{g}$ of ZEN for 2 weeks (Olsen et al., 1986). 
Numerous strategies for cost-effective detoxification of ZEN-contaminated feedstuff have been explored, but these methods have rarely succeeded. The most widely used method of protection against ZEN is the addition of nonnutritive adsorptive materials to the feeds of livestock animals to reduce the bioavailability of ZEN in the gastrointestinal tract.

Biodegradation of ZEN by yeasts in beer and wine or by yeast involved in fermentation or spoilage of food and feeds was investigated by Böswald et al. (1995). Apart from being reduced to ZEN, this toxin is also conjugated to glucose (Chakrabarti \& Ghosal, 1986; Engelhardt et al., 1999; Kamimura, 1986), which is not determined using routine ZEN analytical techniques. Some of these conjugates and natural derivatives are considered more potent estrogens than the parent compound. They may also enter the food chain in animal products such as meat and milk. Studies have been conducted to determine the extent of this secondary source of contamination.

Owing to their effects on the economy as well as livestock and human health, mycotoxins have drawn considerable interest. In the United States and Canada, the cost associated with the impact of mycotoxins on the feed and livestock industry is approximately US $\$ 5$ billion. Although food contamination does not present a challenge in developed countries, mycotoxin contamination largely affects the agricultural economy as well as animal and human health in poorer countries (Fokunang et al., 2006). Supplementation of Fusarium mycotoxin-contaminated grains with yeast cell walls failed to prevent mycotoxin-induced reduction in feed intake and poor growth performance in pigs (Dänicke et al., 2007; Díaz-Llano \& Smith, 2007; Swamy et al., 2002, 2003). To counter the effects of some mycotoxins, aluminosilicate clays have been successfully used as adsorbents and binders for small water-soluble mycotoxins such as aflatoxins in the animal feed industry (Abbès et al., 2006; Chestnut et al., 1992; Daković et al., 2005, 2007; Dixon et al., 2008).

Previous attempts to prevent the effects of ZEN in livestock by using adsorbents have mostly been ineffective. The current study aimed to evaluate the degradative effect of adding different types of adsorbents to complete ZEN-contaminated chicken feed by in vitro simulated digestion.

\section{Materials and methods}

\subsection{Chemicals and adsorbents}

Purified ZEN was purchased from Fermentek (Jerusalem, Israel). WEKLOU was purchased from HAWEPUS (Germany). The main components are calcium propionate, propionic acid; acetic acid, benzoic acid, sorbic acid, buffer. and carriers. KLX mainly composed of yeast cell wall polysaccharide and carriers (hydrated aluminosilicate) was purchased from Angel Yeast Co., Ltd. (Yichang Hubei, China). Medical stone mostly composed of inorganic silicate was supplied by Shen Shi Medical Stone Artware Co., Ltd. (Qiqihar Heilongjiang, China). ZEN and three types of adsorbents were homogenously mixed into complete feed.

\subsection{Preparation of ZEN-contaminated complete feed}

ZEN was added to the complete feed as a ZEN premix prepared by dissolving purified ZEN in a methanol solution $(\geq 99.5 \%)$. The solution was left overnight to allow methanol evaporation, and the feed was mixed thoroughly. The feed was prepared in one batch, which was stored in covered containers prior to the test.

\subsection{Diets and treatments}

The complete feed for the layers was prepared using corn, soybean meal, bran, mountain flour, and Premix. The percentage of components was measured in accordance with GB/T 59162008 (Standardization Administration of China, 2008).

Treatments were prepared: 1) Complete feed $+30 \mathrm{mg} / \mathrm{kg}$ of ZEN; 2) Control $+2 \mathrm{~g} / \mathrm{kg}$ of KLX $+30 \mathrm{mg} / \mathrm{kg}$ of ZEN; 3 ) Complete feed $+3 \mathrm{~g} / \mathrm{kg}$ of WEKLOU $+30 \mathrm{mg} / \mathrm{kg}$ of ZEN. 4) Complete feed $+5 \mathrm{~g} / \mathrm{kg}$ medical stone $+30 \mathrm{mg} / \mathrm{kg}$ of ZEN .

\subsection{In vitro bionic digestion}

The in vitro bionic digestion system used in this study was invented by Feng et al. (2009). The system comprises three compartments simulating the stomach, small intestine forepart, and small intestine posterior segment. A schematic of the monogastric in vitro bionic digestion system is presented in Figure 1. The optimal hydrolysis time for the stages of simulated digestion in a bionic digestion system designed for poultry was determined (Yu-tian et al, 2010). During the experiments, the temperature was kept at $41{ }^{\circ} \mathrm{C}$. Gastric, small intestine forepart, and small intestine posterior segment were simulated. The digestion process was conducted for $1 \mathrm{~h}$. During the first $4 \mathrm{~h}$, the gastric content was digested using a simulated gastric fluid. The digested product was then washed with distilled water at $1500 \mathrm{~mL} /$ time for $40 \mathrm{~min} /$ time, repeated three times. The subsequent stage was the intestinal phase, which was the average, divided into the "small intestine forepart" and the "small intestine posterior segment". The duration of each phase was $7.5 \mathrm{~h}$. Finally, the digested product of the intestine was washed with distilled water at $1500 \mathrm{~mL} /$ time, $40 \mathrm{~min} /$ time, repeated six times. The specific parameters are presented in Table 1. Products of digestion and solution were absorbed from the stomach and intestine by pumping dialysate via hollow fiber membranes with a molecular weight cut-off of approximately 14000 Dalton. ZEN released from the feed matrix during digestion could be either absorbed via the semipermeable membrane systems or bound to the adsorbents.

\subsection{Digestive solution of gastric and intestine}

A gastric electrolyte solution was prepared with $1.085 \mathrm{~g} / \mathrm{L}$ $\mathrm{NaCl}$ and $0.785 \mathrm{~g} / \mathrm{L} \mathrm{KCl} ; 2 \mathrm{~mol} / \mathrm{L} \mathrm{HCl}$ was used to adjust $\mathrm{pH}$ to 2.0 under $41^{\circ} \mathrm{C}$.

The small intestine forepart solution was prepared with $4.675 \mathrm{~g} / \mathrm{L} \mathrm{Na}_{2} \mathrm{HPO}_{4}, 20.045 \mathrm{~g} / \mathrm{L} \mathrm{NaH}_{2} \mathrm{PO}_{4}, 5.565 \mathrm{~g} / \mathrm{L} \mathrm{NaCl}$, $1.545 \mathrm{~g} / \mathrm{L} \mathrm{KCl}$, and 0.8 million $\mathrm{U}$ penicillin; $1 \mathrm{~mol} / \mathrm{L} \mathrm{H}_{3} \mathrm{PO}_{4}$ or $1 \mathrm{~mol} / \mathrm{L} \mathrm{NaOH}$ is used to adjust $\mathrm{pH}$ to 6.5 at $41^{\circ} \mathrm{C}$. 


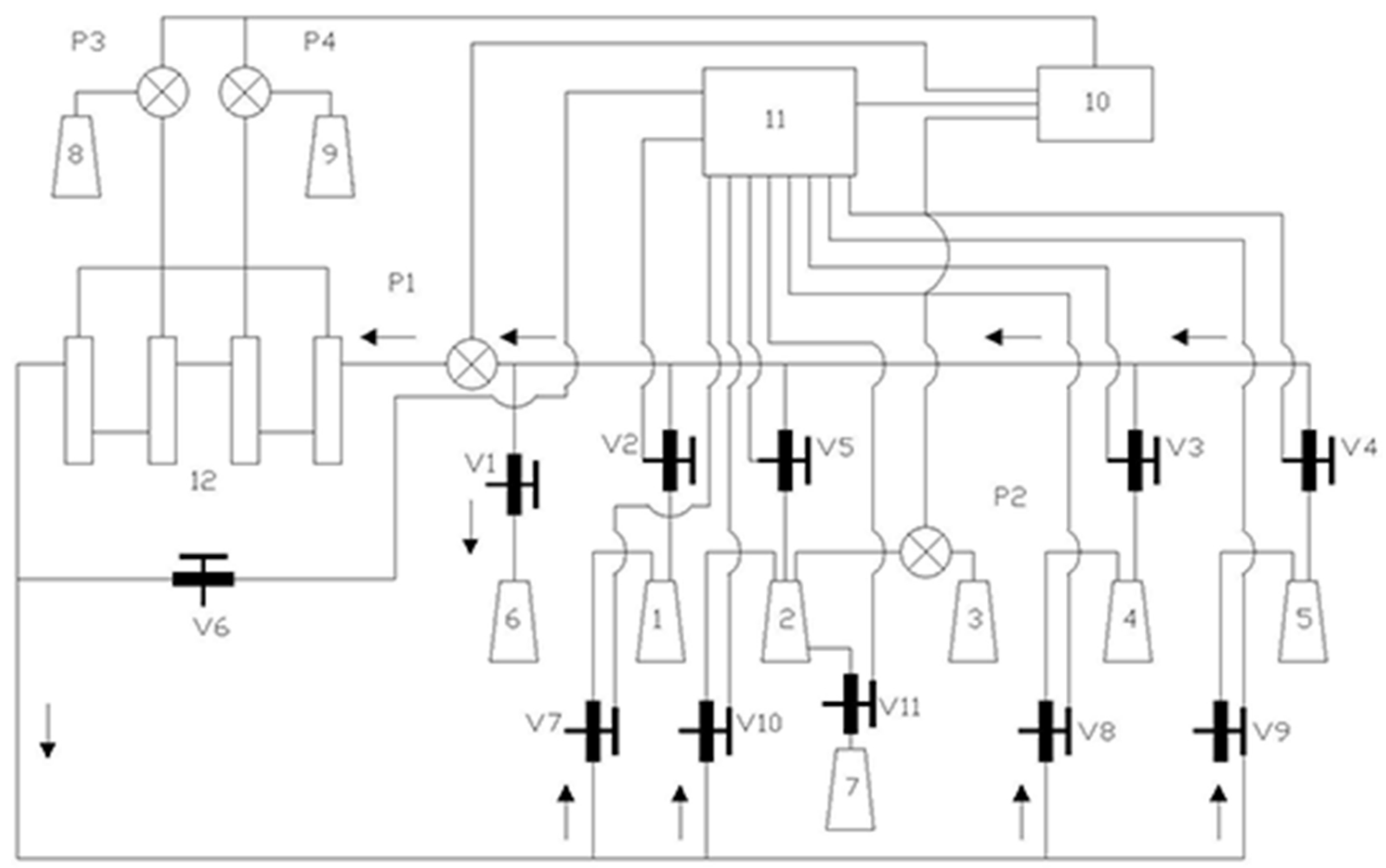

Figure 1. Monogastric animal bionic digestive system. 1-9, reagent bottle; 10, computer, 11, programmable controller, 12, bionic digester, P1P4, peristaltic pump; V1-V11, electromagnetic valve. Bottles 1, stomach buffer solution; Bottle 4, small intestine buffer solution; Bottle 5, large intestine buffer solution; Bottle 2, cleaning solution; Bottle 3, distilled water; Bottles 6 and 7, waste liquid; Bottle 8, small intestine digestive solution; and Bottle 9, large intestine digestive solution.

Table 1. Parameters and conditions for the bionic digestive system.

\begin{tabular}{|c|c|c|c|}
\hline \multicolumn{2}{|c|}{ Bionic digestive system in stomach stage } & \multicolumn{2}{|c|}{ Bionic digestive system in small intestine stage } \\
\hline temperature & $41^{\circ} \mathrm{C}$ & temperature & $41^{\circ} \mathrm{C}$ \\
\hline Digestive time & $4 \mathrm{~h}$ & Digestive time & Forepart $7.5 \mathrm{~h}+$ posterior segment $7.5 \mathrm{~h}$ \\
\hline Cleaning fluid & $1500 \mathrm{~mL} /$ time & Cleaning fluid & $1500 \mathrm{~mL} /$ time \\
\hline Cleaning time & $40 \mathrm{~min} /$ time & Cleaning time & $40 \mathrm{~min} /$ time \\
\hline Pepsin & $387.5 \mathrm{KU}$ & Amylase & $110.40 \mathrm{KU}$ \\
\hline- & - & Trypsin & $13.55 \mathrm{KU}$ \\
\hline- & - & Chymotrypsin & $3.11 \mathrm{KU}$ \\
\hline
\end{tabular}

The small intestine posterior segment solution was prepared using $24.385 \mathrm{~g} / \mathrm{L} \mathrm{Na}_{2} \mathrm{HPO}_{4}, 3.385 \mathrm{~g} / \mathrm{L} \mathrm{NaH}_{2} \mathrm{PO}_{4}, 5.015 \mathrm{~g} / \mathrm{L} \mathrm{NaCl}$, $1.395 \mathrm{~g} / \mathrm{L} \mathrm{KCl}$, and $0.8 \mathrm{million} \mathrm{U}$. Subsequently, $1 \mathrm{~mol} / \mathrm{L} \mathrm{H}_{3} \mathrm{PO}_{4}$ or $1 \mathrm{~mol} / \mathrm{L} \mathrm{NaOH}$ is used to adjust the $\mathrm{pH}$ to 7.99 at $41^{\circ} \mathrm{C}$.

The simulated gastric fluid consisting of $387.5 \mathrm{kU}$ of pepsin (Sigma P7000) was dissolved in $250 \mathrm{~mL} \mathrm{HCl}$ (adjusted to $\mathrm{pH} 2.0$ at $41^{\circ} \mathrm{C}$ ).

The simulated intestinal fluid containing $13.55 \mathrm{kU}$ trypsin (Amresco 0785) and $3.11 \mathrm{kU}$ chymotrypsin (Amresco 0164) were dissolved in $25 \mathrm{~mL}$ deionized water, stirred to dissolve, and added to $110.40 \mathrm{kU}$ amylase (Sigma A3306).

\subsection{Sample collection for bionic digestion analysis}

Samples collected from the monogastric animal bionic digestive system (gastric plus small intestine forepart and small intestine posterior segment digestive fluids and the final chyme), which consisted of a liquid phase and an undigested 
solid feed material, were centrifuged. After the solid residue was discarded, supernatant aliquots were used for ZEN analysis. The digestive fluid samples we obtained were filtered via a dialysis tube (MEMBRA-CEL MD34-14, Viskase Int. Ltd, USA).

\subsection{Determination and analysis of ZEN}

ZEN extract from the digestive product was mixed with PBS at equal volumes $(0.01 \mathrm{M})$, and $100 \mathrm{uL}$ of the extract was taken for testing by indirect competitive enzyme-linked immunosorbent assay (ELISA) by using prepared monoclonal antibodies (Pei et al., 2013). Standard curves were obtained by plotting the ZEN standard values against the optical density at A450.

\subsection{Calculation and statistical analysis of data}

Statistical analyses were performed by one-way ANOVA and Tukey-Kramer multiple comparisons test, with differences considered significant at $P<0.05$.

The percentage of ZEN residues calculated in the stomach digestive fluids, small intestine forepart, and small intestine posterior segment fluid indicated the fraction of free ZEN not absorbed from the chyme. The solid residues of samples collected from the bionic digestion system, analyzed for ZEN, comprised the amount of ZEN for absorption and degradation by two different adsorbents.

\section{Results}

\subsection{Diet manufacturing}

The complete feed for layers was manufactured in accordance with GB/T 5916-2008 (Standardization Administration of China, 2008). All nutrient concentrations were formulated to meet or exceed minimal requirements (Table 2).

\subsection{Operating the bionic digestive system}

The effective procedures for the bionic digestion of layers were determined after several preliminary tests. The ZEN-binding capacity of the adsorbents and the in vitro system designed to mimic the temperature were assessed based on the $\mathrm{pH}$ and the duration of passage via the stomach and the gut of a monogastric animal. Details on the parameter and condition of the bionic digestive system are listed in Table 1.

\subsection{Residues of ZEN in different digestive fluids with three kinds of adsorbents}

In this study, a $1 \mathrm{~kg}$ batch of artificially contaminated complete feed was used to feed the bionic digestion system. The feed was homogeneously distributed with ZEN at a concentration of $30 \mathrm{mg} / \mathrm{kg}$. ZEN from spiked dialysate samples (stomach digestive fluids, small intestine forepart, and small intestine posterior segment digestive fluids) had recovery rates of $93 \% \pm 2 \%$.

ZEN adsorption was assessed by ELISA of the unbound fraction in incubation filtrates from three individual experiments using binders with varying concentrations: $2 \mathrm{~g} / \mathrm{kg}$ of KLX, $3 \mathrm{~g} / \mathrm{kg}$ WEKLOU, and $5 \mathrm{~g} / \mathrm{kg}$ medical stone. Table 3 lists the ZEN adsorption levels exhibited by calcium propionate, propionic acid, and so on, in addition to the yeast cell wall material and inorganic silicate. KLX was determined as the most effective compound and yeast cell was as the main component.

The amounts of ZEN (expressed as a percentage of the intake) in the samples collected after gastrointestinal digestion of the control and test meals for 0-19 h are listed in Table 3. ZEN was diffused via dialysis membranes from both stomach and small intestine compartments. When no sequestering materials were added to the meal (control), the total stomach absorption of ZEN was $71 \%$ of the intake, and the total small intestine absorption of ZEN (corresponding to the amount of ZEN in small intestine forepart + posterior segment dialysate fluids) was $24 \%$ of the intake (Table 3). Most of the ZEN absorbed came from the small intestine forepart (16\%), and the remaining amount came from the posterior segment (9\%). In the liquid fraction of the stomach + duodenum residues, only $4 \%$ of the initial ZEN was found, indicating that at the end of the digestion process, ZEN was almost entirely delivered from the gastric and duodenal compartments into the jejunum and ileum. ZEN thus became potentially available for absorption. In the chyme residues, $4 \%$ of the ZEN intake was found, suggesting that part of the toxin was bound to feed particles within the dialysis units, the dialysis membrane, or both.

Table 2. Ingredients and components of the complete feed.

\begin{tabular}{lccc}
\hline Ingredients & Percentage (\%) & Nutrients & Analyzed values \\
\hline Corn & 63.0 & Crude protein (\%) & 16.5 \\
Soybean meal & 23.0 & Lysine (\%) & 0.76 \\
Bran & 4.0 & Methionine + Cysteine (\%) & 0.65 \\
Mountain flour & 5.0 & Calcium (\%) & 3.50 \\
Premix & 5.0 & Total phosphorus (\%) & 0.60 \\
& & Available phosphorus (\%) & 0.33 \\
& & Metabolic energy (kcal/kg) & 2650 \\
\hline
\end{tabular}

${ }^{a}$ Supplied per kg of diet: vitamin A, $200000 \mathrm{IU}$; vitamin $\mathrm{D}_{3}, 76000 \mathrm{IU}$; vitamin E, $650 \mathrm{IU}$; vitamin $\mathrm{K}_{3}, 58 \mathrm{mg}$; vitamin $\mathrm{B}_{1}, 45 \mathrm{mg}$; vitamin $\mathrm{B}_{2}, 180 \mathrm{mg}$; vitamin $\mathrm{B}_{6}, 30 \mathrm{mg}$; vitamin $\mathrm{B}_{12}$, $4.0 \mathrm{mg}$; nicotinic acid, $800 \mathrm{mg}$; pantothenic acid, $400 \mathrm{mg}$; folic acid, $12 \mathrm{mg}$; biotin, $1.8 \mathrm{mg}$; choline chloride, 9 g; Fe, $1600 \mathrm{mg}$; Cu, $165 \mathrm{mg}$; Zn, $1400 \mathrm{mg}$; Mn, $2000 \mathrm{mg}$; I, $10 \mathrm{mg}$; Se, $7 \mathrm{mg} ; \mathrm{Ca}, 120 \mathrm{~g} ; \mathrm{P}, 25 \mathrm{~g}$. 
Table 3. Mean $( \pm$ SEM; $n=4)$ of zearalenone in samples collected from the vitro bionic digestion of ZEN-contaminated feed without (control) and with KLX, WEKLOU, and medical stone at different inclusion levels.

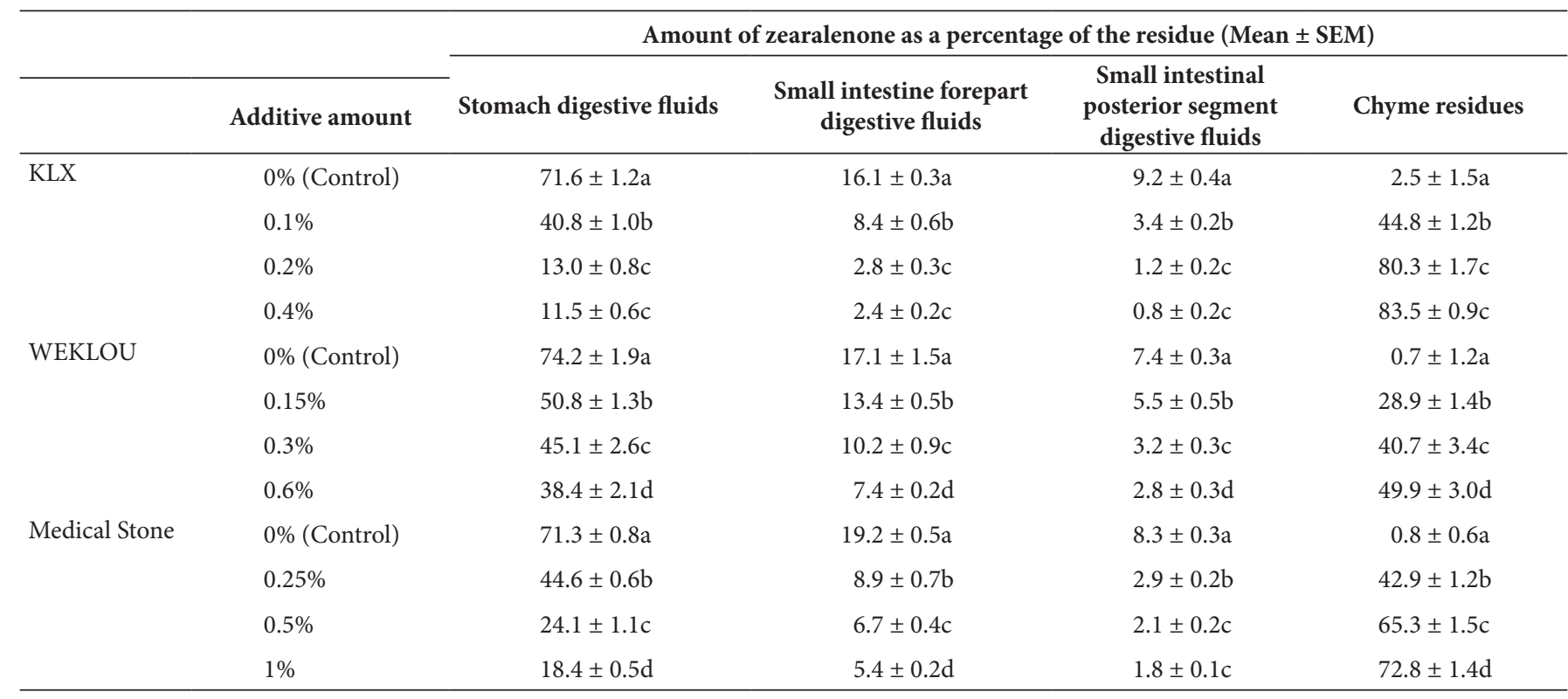

Values in columns followed by the same letters are not significantly different.

A significant reduction in the stomach and intestinal absorption of ZEN $(P<0.05)$ was observed after KLX, WEKLOU, and medical stone at all inclusion levels (from low to high) were added. KLX exhibited a more pronounced effect than those of WEKLOU and medical stone. With the addition of low to high percentage levels of KLX or WEKLOU and medical stone, ZEN absorption was reduced by $47-85 \%$ or $30-51 \%$ and $43-74 \%$, respectively, relative to that of the control (Figure 2).

Three kinds of adsorbents effectively sequestered ZEN from chyme residues. The ZEN reductions in the ileal deliveries, stomach + duodenum residues, and jejunum + ileum residues were $88 \%, 87 \%$, and $69 \%$, respectively, with activated carbon and $83 \%, 60 \%$, and $59 \%$ with cholestyramine. This finding showed that when ZEN was in the soluble phase of chyme, it was strongly sequestered by KLX, WEKLOU, and medical stone (Table 3). The dialysate samples taken at different times (0-4, 4-11.5, 11.5-19 h) showed that ZEN was adsorbed at different rates during digestion in the presence of KLX, WEKLOU, and medical stone (Figure 3). In the absence of adsorbent materials, the amounts of ZEN measured in the dialysate fluid samples collected over different periods were $72 \%(0-4 \mathrm{~h}), 17 \%(4-11.5 \mathrm{~h})$, and $8 \%(11.5-19 \mathrm{~h})$ of the residue. The maximum amount of ZEN was measured in the stomach digestive fluids collected during the $0-4 \mathrm{~h}$ period when almost $75 \%$ of the gastric content was delivered into the small intestine and was potentially available for digestion and absorption. When $0.4 \%$ of KLX or $0.6 \%$ of WEKLOU or $1 \%$ of medical stone was included in the feed, strong ZEN-binding occurred during the initial period of $4 \mathrm{~h}$ and was persistent for the remaining period of the experiment.

Among the three inclusion levels tested in this study, $0.2 \%$ of KLX and $0.6 \%$ of WEKLOU and $0.5 \%$ of medical stone exerted the maximum significant effect on the prevention of ZEN absorption in the intestine $(P<0.05)$.

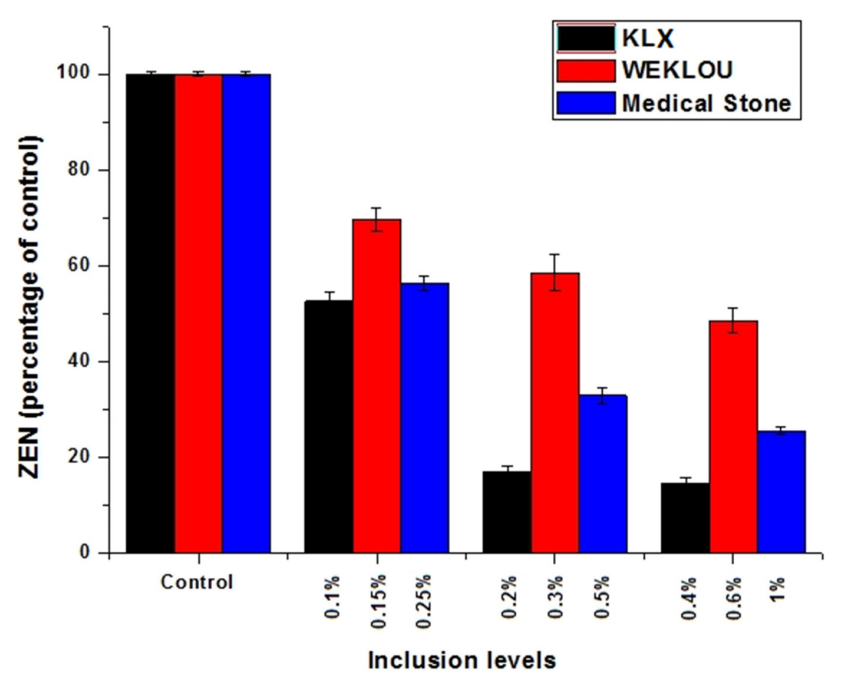

Figure 2. Mean ( \pm SEM; $n=4$ ) percentage of $Z E N$ residue in stomach and small intestine dialysate fluids collected from the bionic digestive system during digestion of a ZEN-contaminated feed with KLX, WEKLOU, and medical stone at different inclusion levels for $19 \mathrm{~h}$. Control (100\%) represents the amount of ZEN recovered under the same experimental conditions without adsorbent additives.

\section{Discussion}

Prevention as a complementary strategy to mycotoxin decontamination is an important issue. Any approach generally aimed to reduce the toxic and economic effects of mycotoxins should respond to as many of the following requisites as possible: (1) prevents, destroys, removes, or detoxifies mycotoxins in foods and feeds; (2) does not produce or leave toxic and/or 

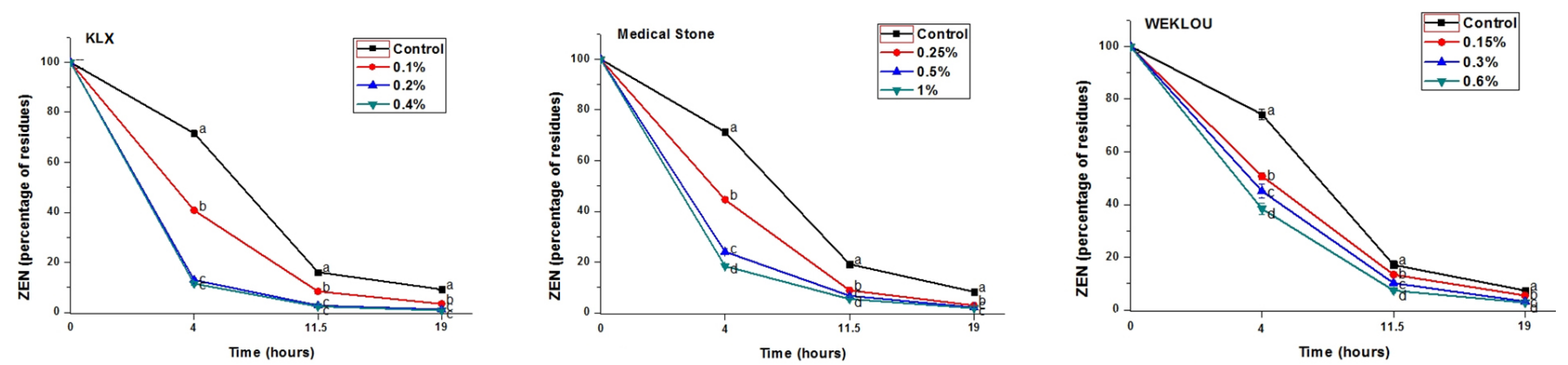

Figure 3. Time course of the amount of ZEN (as a percentage of the residues) measured in different digestive stages dialysate fluid samples collected from the bionic digestive system during digestion of a ZEN-contaminated meal without (control) and with three kinds of absorbents at different inclusion levels.

carcinogenic or mutagenic residues in the final products; (3) does not significantly alter the important technological and nutritional properties of the food or feed; (4) is technically and economically feasible (Awad et al., 2010; Galvano et al., 2001; Kabak et al., 2006; Park et al., 2002).

The yeast cell walls have excellent nutritional value, apart from also exhibiting potential as absorbents. By using only yeast cell walls instead of whole cells, adsorption of mycotoxins can be enhanced. On the basis of various studies, the interaction of such products with mycotoxins is confirmed to occur by adhering to cell wall components rather than by covalent binding or by metabolism because dead cells do not lose their binding ability (Shetty \& Jespersen, 2006; Shetty et al., 2007).

The $\beta$-D-glucan fraction of yeast cell wall is directly involved in the binding process with ZEA, and the structural organization of $\beta$-D-glucans modulates the binding strength (Jouany, 2007). Aravind et al. (2003) showed that a yeast cell wall product bound $0.054 \mathrm{mg} / \mathrm{kg}$ of ZEN in in vitro assay.

Despite the increasing number of studies on adsorbents, further research still has to be conducted. Numerous interactions between feeds, adsorbents, and mycotoxins have yet to be elucidated. Another critical aspect is the possible effect of adding adsorbents to animal feed on the analytical performance of methods used for mycotoxin determination.

A simple in vitro model (static GI model) was used to evaluate the efficacy of several MB for binding DON and ZEN (Döll et al., 2004). This model simulates the conditions ( $\mathrm{pH}$, temperature, and transit time) in the porcine GI tract, considering that pigs are most sensitive to those mycotoxins. The method demonstrated that Activated Carbon was able to bind both toxins, while cholestyramine and modified aluminosilicate showed good adsorption of ZEN.

In vitro studies do not always predict in vivo results. Adsorption in vivo is complicated by physiological variables and the composition of feeds, which are factors that are rarely considered in vitro. Moreover, animal studies are costly and not easy to perform. However, all potential adsorbents must be tested in vivo to confirm their efficacy and safety, as well as lack of interaction with nutrients. An approach to effective pre- screening of mycotoxin/sorbent combinations before testing on animals has been suggested (Lemke et al., 2001).

\section{Conclusion}

KLX, WEKLOU, and medical stone are good candidates for ZEN detoxification and can be used as feed additives to prevent hyperestrogenism in monogastric animals.

These absorbent materials can also be potentially used as multi-mycotoxin binding agents.

Further studies need to be proved, either using the bionic digestive system or in vivo experiments. The effectiveness of these adsorbent materials in reducing the toxic effects of ZEN without affecting the regular use of essential nutrients, such as vitamins and minerals.

\section{Acknowledgements}

This work was supported by grants from National Science and Technology Foundation Work Project (2013 FY113400), the Fundamental Research Funds in Heilongjiang Province Universities (LTSW201729)(YSTSXK201826), State Key Laboratory of Animal Nutrition of China (No. 2004DA125184F1205); Qiqihar University Young Teacher Research Project (2014kM24), and Science Program Project of Heilongjiang Education Department (12541871). We also thank Hu Zhang, Li Zhang, Jie Gao, Jize Zhang, Lixiang Gao, and Liang Chen (Institute of Animal Science, Chinese Academy of Agricultural Science, Beijing) for their cooperation.

\section{References}

Abbès, S., Ouanes, Z., Ben Salah-Abbès, J., Houas, Z., Oueslati, R., Bacha, H., \& Othman, O. (2006). The protective effect of hydrated sodium calcium aluminosilicate against haematological, biochemical and pathological changes induced by zearalenone in mice. Toxicon, 47(5), 567-574. http://dx.doi.org/10.1016/j.toxicon.2006.01.016. PMid:16563452.

Allen, N. K., Mirocha, C. J., Aakhus-Allen, S., Bitgood, J. J., Weaver, G., \& Bates, F. (1981). Effect of dietary zearalenone on reproduction of chickens. Poultry Science, 60(6), 1165-1174. http://dx.doi.org/10.3382/ ps.0601165. PMid:6455658. 
Aravind, K. L., Patil, V. S., Devegowda, G., Umakantha, B., \& Ganpule, S. P. (2003). Efficacy of esterified glucomannan to counteract mycotoxicosis in naturally contaminated feed on performance and serum biochemical and hematological parameters in broilers. Poultry Science, 82(4), 571-576. http://dx.doi.org/10.1093/ps/82.4.571. PMid:12710475.

Awad, W. A., Ghareeb, K., Böhm, J., \& Zentek, J. (2010). Decontamination and detoxification strategies for the Fusarium mycotoxin deoxynivalenol in animal feed and the effectiveness of microbial biodegradation. Food additives \& contaminants. Part A, Chemistry, analysis, control, exposure \& risk assessment, 27(4), 510-520. http://dx.doi.org/10.1080/19440040903571747. PMid:20234966.

Aziz, N. H., Attia, E. S., \& Farag, S. A. (1997). Effect of gamma- irradiation on the natural occurrence of Fusarium mycotoxins in wheat, flour and bread. Die Nahrung, 41(1), 34-37. http://dx.doi.org/10.1002/ food.19970410109. PMid:9113669.

Betina, V. (1989). Bioactive molecules (Vol. 9, Mycotoxins). Amsterdam: Elsevier.

Böswald, C., Engelhardt, G., Vogel, H., \& Wallnöfer, P. R. (1995). Wallnöfer. Metabolism of the Fusarium mycotoxins zearalenone and deoxynivalenol by yeast strains of technological relevance. Natural Toxins, 3(3), 138-144. http://dx.doi.org/10.1002/nt.2620030304. PMid:7648022.

Chakrabarti, D. K., \& Ghosal, S. (1986). Occurrence of free and conjugated 12,13-epoxytrichothecenes and zearalenone in banana fruits infected with Fusarium moniliforme. Applied and Environmental Microbiology, 51(1), 217-219. http://dx.doi.org/10.1128/AEM.51.1.217-219.1986. PMid:2937364.

Chestnut, A. B., Anderson, P. D., Cochran, M. A., Fribourg, H. A., \& Gwinn, K. D. (1992). Effects of hydrated sodium calcium aluminosilicate on fescue toxicosis and mineral absorption. Journal of Animal Science, 70(9), 2838-2846. http://dx.doi.org/10.2527/1992.7092838x. PMid:1328128.

Chi, M. S., Mirocha, C. J., Weaver, G. A., \& Kurtz, H. J. (1980). Effect of zearalenone on female white leghorn chickens. Applied and Environmental Microbiology, 39(5), 1026-1030. http://dx.doi. org/10.1128/AEM.39.5.1026-1030.1980. PMid:6446881.

D’Mello, J. P. E., Placinta, C. M., \& Macdonald, A. M. C. (1999). Fusarium mycotoxins: a review of global implications for animal health, welfare and productivity. Animal Feed Science and Technology, 80(3-4), 183205. http://dx.doi.org/10.1016/S0377-8401(99)00059-0.

Daković, A., Matijasević, S., Rottinghaus, G. E., Dondur, V., Pietrass, T., \& Clewett, C. F. M. (2007). Adsorption of zearalenone by organomodified natural zeolitic tuff. Journal of Colloid and Interface Science, 311(1), 8-13. http://dx.doi.org/10.1016/j.jcis.2007.02.033. PMid:17368471.

Daković, A., Tomasević-Canović, M., Dondur, V., Rottinghaus, G. E., Medaković, V., \& Zarić, S. (2005). Adsorption of mycotoxins by organozeolites. Colloids and Surfaces. B, Biointerfaces, 46(1), 20-25. http://dx.doi.org/10.1016/j.colsurfb.2005.08.013. PMid:16198090.

Dänicke, S., Brüssow, K.-P., Goyarts, T., Valenta, H., Ueberschär, K.-H., \& Tiemann, U. (2007). On the transfer of the Fusarium toxins deoxynivalenol (DON) and zearalenone ( $\mathrm{ZON}$ ) from the sow to the full-term piglet during the last third of gestation. Food and Chemical Toxicology, 45(9), 1565-1574. http://dx.doi.org/10.1016/j.fct.2007.02.016. PMid:17399880.

Díaz-Llano, G., \& Smith, T. K. (2007). The effects of feeding grains naturally contaminated with Fusarium mycotoxins with and without a polymeric glucomannan adsorbent on lactation, serum chemistry, and reproductive performance after weaning of firstparity lactating sows. Journal of Animal Science, 85(6), 1412-1423. http://dx.doi.org/10.2527/jas.2006-213 PMid:17325124.

Dixon, J. B., Kannewischer, I., Tenorio Arvide, M. G., \& Barrientos Velazquez, A. L. (2008). Aflatoxin sequestration in animal feeds by quality-labeled smectite clays: an introductory plan. Applied Clay Science, 40(1-4), 201-208. http://dx.doi.org/10.1016/j.clay.2007.10.010.
Döll, S., Dänicke, S., Valenta, H., \& Flachowsky, G. (2004). In vitro studies on the evaluation of mycotoxin detoxifying agents for their efficacy on deoxynivalenol and zearalenone. Archives of Animal Nutrition, 58(4), 311-324. http://dx.doi.org/10.1080/00039420412 331273268. PMid:15570745.

Dowling, T. S. (1997). Fumonisins and its toxic effects. Cereal Foods World, 42, 13-15.

Engelhardt, G., Ruhland, M., \& Wallnöfer, P. R. (1999). Metabolism of mycotoxins in plants. Advances in Food Sciences, 21, 71-78.

Feng, Z., Hongfu, Z., Qingping, L., Guangyuan, H., \& Ziyi, Z. (2009, Nov 11). The monogastric animals bionic digestive system. China invention patent. No. CN200920105936.5.

Fokunang, C. N., Tembe-Fokunang, E. A., Tomkins, P., \& Barkwan, S. (2006). Global impact of mycotoxins on human and animal health management. Outlook on Agriculture, 35(4), 247-253. http://dx.doi.org/10.5367/000000006779398263.

Galvano, F., Piva, A., Ritieni, A., \& Galvano, G. (2001). Dietary strategies to counteract the effects of mycotoxins: a review. Journal of Food Protection, 64(1), 120-131. http://dx.doi.org/10.4315/0362028X-64.1.120. PMid:11198434.

Groves, F. D., Zhang, L., Chang, Y. S., Ross, P. F., Casper, H., Norred, W. P., You, W. C., \& Fraumeni, J. F. Jr. (1999). Fusarium mycotoxins in corn and corn products in a high risk area for gastric cancer in Shandong Province, China. Journal of AOAC International, 82(3), 657-662. http://dx.doi.org/10.1093/jaoac/82.3.657. PMid:10367384.

Joint FAO/WHO Expert Committee on Food Additives - JECFA. (2000). 53rd report: safety evaluation of certain food additives and contaminants (WHO Food Additives Series, No. 44). Geneva.

Jouany, J. P. (2007). Methods for preventing, decontaminating and minimizeing the toxicity of mycotoxins in feeds. Animal Feed Science and Technology, 137(3-4), 342-362. http://dx.doi.org/10.1016/j. anifeedsci.2007.06.009.

Kabak, B., Dobson, A. D. W., \& Var, I. (2006). Strategies to prevent mycotoxin contamination of food and animal feed: a review. Critical Reviews in Food Science and Nutrition, 46(8), 593-619. http://dx.doi.org/10.1080/10408390500436185. PMid:17092826.

Kamimura, H. (1986). Conversion of zearalenone to zearalenone- glycoside by Rhizopussp. Applied and Environmental Microbiology, 52(3), 515-519. http://dx.doi.org/10.1128/AEM.52.3.515-519.1986. PMid:2945513.

Lemke, S. L., Mayura, K., Reeves, W. R., Wang, N., Fickey, C., \& Phillips, T. D. (2001). Investigation of organophilic montmorillonite clay inclusion in zearalenone-contaminated diets using the mouse uterine weight bioassay. Journal of Toxicology and Environmental Health. Part A., 62(4), 243-258. http://dx.doi.org/10.1080/009841001459405. PMid:11245394.

Martin, P. M. D., \& Keen, P. (1978). The occurrence of zearalenone in raw fermented products from Swaziland and Lesotho. Sabouraudia, 16(1), 15-22. http://dx.doi.org/10.1080/00362177885380031. PMid:635723.

Okoye, Z. S. S. C. (1987). Stablity of zearalenone in naturally contaminated corn during Nigerian traditional brewing. Food Additives and Contaminants, 4(1), 57-59. http://dx.doi.org/10.1080/02652038709373615. PMid:2951281.

Olsen, M., Mirocha, C. J., Abbas, H. K., \& Johansson, B. (1986). Metabolism of high concentrations of dietary zearalenone by young male turkey poults. Poultry Science, 65(10), 1905-1910. http://dx.doi.org/10.3382/ps.0651905. PMid:2948167.

Park, J. W., Kim, E. K., Shon, D. H., \& Kim, Y. B. (2002). Occurrence of zearalenone in Korean barley and corn foods. Food Additives and Contaminants, 19(2), 158-162. http://dx.doi. org/10.1080/02652030110071345. PMid:11820497. 
Pei, S.-C., Lee, W.-J., Zhang, G.-P., Hu, X.-F., Eremin, S. A., \& Zhang, L.-J. (2013). Development of anti-zearalenone monoclonal antibody and detection of zearalenone in corn products from China by ELISA. Food Control, 31(1), 65-70. http://dx.doi.org/10.1016/j. foodcont.2012.09.006.

Pittet, A. (1998). Natural occurrence of mycotoxins in foods and feeds - an updated review. Revue Met. Vet., 149(6), 479-492.

Schneweis, I., Meyer, K., Engelhardt, G., \& Bauer, J. (2002). Occurrence of zearalenone-4-beta-D-glucopyranoside in wheat. Journal of Agricultural and Food Chemistry, 50(6), 1736-1738. http://dx.doi.org/10.1021/jf010802t. PMid:11879067.

Shetty, P. H., \& Jespersen, L. (2006). Saccharomyces cerevisiae and lactic acid bacteria potential mycotoxin decontaminating agents. Trends in Food Science \& Technology, 17(2), 48-55. http://dx.doi.org/10.1016/j.tifs.2005.10.004.

Shetty, P. H., Hald, B., \& Jespersen, L. (2007). Surface binding of aflatoxin B1 by Saccharomyces cerevisiae strains with potential decontaminating abilities in indigenous fermented foods. International Journal of Food Microbiology, 113(1), 41-46. http://dx.doi.org/10.1016/j. ijfoodmicro.2006.07.013. PMid:16996157.

Standardization Administration of China - SAC. (2008). GB/T 5916-2008: formula feeds for replacement pullets, layers and broilers. Beijing.

Swamy, H. V. L. N., Smith, T. K., MacDonald, E. J., Boermans, H. J., \& Squires, E. J. (2002). Effects of feeding a blend of grains naturally contaminated with Fusarium mycotoxins on swine performance, brain regional neurochemistry, and serum chemistry and the efficacy of a polymeric glucomannan mycotoxin adsorbent. Journal of Animal Science, 80(12), 3257-3267. http://dx.doi.org/10.2527/2002.80123257x. PMid:12542167.

Swamy, H. V. L. N., Smith, T. K., MacDonald, E. J., Karrow, N. A., Woodward, B., \& Boermans, H. J. (2003). Effects of feeding a blend of grains naturally contaminated with Fusarium mycotoxins on growth and immunological measurements of starter pigs, and the efficacy of a polymeric glucomannan mycotoxin adsorbent. Journal of Animal Science, 81(11), 2792-2803. http://dx.doi.org/10.2527/2003.81112792x. PMid:14601883.

Tanaka, T., Hasegawa, A., Yamamoto, S., Lee, U. S., Sugiura, Y., \& Ueno, Y. (1988). Worldwide contamination of cereals by the Fusarium mycotoxins, nivalenol, deoxynivalenol, and zearalenone. 1. Survey of 19 countries. Journal of Agricultural and Food Chemistry, 36(5), 979-983. http://dx.doi.org/10.1021/jf00083a019.

Urry, W. H., Wehrmeister, H. L., Hodge, E. B., \& Hidy, P. H. (1966). The structure of zearalenone. Tetrahedron Letters, 27(27), 3109-3114. http://dx.doi.org/10.1016/S0040-4039(01)99923-X.

Yu-tian, L., Feng, Z., Hong-fu, Z., Wei-kuan, Z., \& Yong-jun, W. (2010). The optimum hydrolysis time for simulative digestion stages in a bionic digestion system designed for poultry. Chinese Journal of Animal Nutrition, 22(5), 1422-1427.

Zhang, X., Liu, W., Logrieco, A. F., Yang, M., Ou-yang, Z., Wang, X., \& Guo, Q. (2011). Determination of zearalenone in traditional Chinese medicinal plants and related products by HPLC-FLD. Food Additives and Contaminants, 28(7), 885-893. http://dx.doi.org/10.1080/1944 0049.2011.563429. PMid:21547799. 